\title{
Fair Use Doctrine in Photocopying Books for Educational Purposes: A Study of Copyright Acts in Indonesia and the United States
}

\author{
Nadiya Nurmaya* \\ University of Jember, Indonesia
}

Mardi Handono

University of Jember, Indonesia

Galuh Puspaningrum

University of Jember, Indonesia

\begin{abstract}
Globalization has offered a multitude of opportunities and challenges, mainly when it deals with copyright. The scope of copyright has been broad, encompassing various aspects of life, especially in literature and education. This study aims to analyze Indonesia's copyright issues, particularly regarding the reproduction of books deemed to have lesser protection for authors, dealing with the fair use doctrine. This doctrine considers that work is allowed to a limited extent for use by other parties without the creator or copyright holder's permission to keep it fair. This fair use doctrine permits limited and fair use of literary works for specific purposes without royalty payments and the author's consent. Given the author's more protection, this study then displays a comparative analysis of the U.S. framework on the Copyright Act portrayed into two main discussions. First, this study will discuss photocopying for educational purposes from the lens of Indonesia's Copyright Act. Second, this study considers the possible adjustment to adopt the so-called future concept of restrictions for educational purposes from the U.S. States Copyright Act 1976.
\end{abstract}

KEYWORDS: Fair Use Doctrine, Copyright Act, Copyright for Educational Purposes.

Submitted: 11/06/2020 Reviewed: 12/06/2020 Revised: 15/07/2020 Accepted: 20/07/2020

Copyright $\odot 2020$ by Author(s)

This work is licensed under a Creative Commons Attribution-ShareAlike 4.0 International License. All writings published in this journal are personal views of the authors and do not represent the views of this journal and the author's affiliated institutions

*Corresponding authors' e-mail: nadiyanurmaya25@gmail.com 


\section{INTRODUCTION}

Copyright's dramatic legal development started from establishing the Berne Convention for Protection of Literary and Artistic Works as the first convention in this field. The minimum obligations of convention member countries to protect literary and artistic works creators are emphasized in the Berne Convention's main provisions. The Berne Convention then became a reference to the Agreement on Trade-Related Aspects of Intellectual Property Rights (TRIPs Agreement) and World Intellectual Property Organization Copyright Treaty 1996 (WIPO Copyright Treaty). One of its kinds is the book as protected by international agreement and national legislation such as Indonesia's Copyright Act 2014 and the U.S. Copyright Act 1976.

The consequence of this arrangement that includes the book as part of copyright aims to protect the author from potential infringements from other authors, like reproducing the text without permission from the book's author. It asserts that other parties may only reproduce with the consent of the author. However, to thrive in encouraging science and creativity and balance the interests of authors and public interests in education and research, the Berne Convention sets the procedure of limitation or reproduction as outlined in Article 9. Also, the Berne Convention refers to Article 13 TRIPs Agreement regarding exception, which displays a threestep test.

The TRIPs Agreement as a continuation of the Berne Convention briefly stipulates that member countries must comply with the provisions from Articles 1 to 21 the Berne Convention. These mandatory provisions are subsequently contained in Article 9 (1) TRIPs Agreement. An exception also accompanies this article to the right and obligation referencing to implement Article 6. The Berne Convention and the TRIPs Agreement provide leniency to formulate their laws and regulations while still referring to the Berne Convention and the TRIPs Agreement because of these rules' binding nature.

Indonesia then ratified the Berne Convention and the TRIPs Agreement. As a country with a civil law tradition, the exception to copyright in 
Indonesia is copyright limitation. This term is a concept in the civil law system that starts point for copyright protection given to a copyrighted work or object. Restrictions in the copyright act aim to regulate industrialization and commercial trade practices as well as fair competition. One of the limitations of copyright is for educational purposes. Since the early development of the copyright act, the importance of educational purposes restrictions has been recognized. Currently, restrictions are closely related to intergenerational equality for future generations' benefit as two sides of the coin, so-called today's users are authors or writers' tomorrow.

This limitation is often questioned, especially by authors, against photocopying books for educational purposes excepted in Article 44 (1) of the Indonesia Copyright Act. This provision is more directed towards qualitative limitations. This is because the interest of education as one of the exceptions to copyright in the article does not explain the definitions, criteria, and limitations allowed to use a work for educational interests. These provisions do not explain the meaning or criteria of educational interests, either for educational purposes of a commercial or non-commercial nature or educational purposes for private or public use. With a note, even though it is for personal and non-commercial purposes, it still cannot harm the creator or copyright holder.

The absence of a limit on the number of works allowed or reproduced in books creates confusion in the community. For example, it is the case of a student photocopying book's entire contents, including the most substantial part of the book. However, they still include the author's name to be used as learning for educational purposes. It has become prevalent because there is no explicit limit on how much reproduction can be done not to harm the author. Unfortunately, regarding this attitude, there remains no affirmation that it goes beyond the meaning of the purpose of education itself. As a result, there are not only one or two who carry out this act of reproduction. Many of them still do not understand the meaning of appreciating work. It lasts to assume that reproducing books for educational purposes is a common thing. In contrast, it harms the author's economic interests. 
Given such a prevalent attitude, Indonesia Copyright Act 2014 needs to refer to the U.S. Copyright Act 1976. In the context, the United States' policy in this field refers to international agreements, despite its common law tradition. As a result, the term given to the exception of copyright is fair use. This doctrine considers that work is allowed to a limited extent for use by other parties without the creator or copyright holder's permission to keep it fair. This fair use doctrine permits limited and fair use of literary works for specific purposes without royalty payments and the author's consent. These objectives are set in Section 107 Copyright Act 1976, which explicitly parameters regarding the limits to determine fair use are apparent. There are four factors in it. First, the purpose and character of the use, including whether the use is commercial or for non-profit educational purposes. Second, the nature of work. Third, the amount and substance of the portion used. Fourth, the economic consequences of use. To determine whether a work is a fair use, these four factors are interrelated and move simultaneously. The regulation regarding book reproduction in the U.S. is quite detailed and strict. This precise and strict regulation shows a higher awareness of the importance of copyright in the U.S. society responded by the government to provide a legal basis for protection. Thus, Indonesia's current challenges and opportunities can refer to the existing U.S. Copyright Act even though both countries have different legal systems and traditions. To be sure, it is not an excuse for creating a dichotomy between the two. According to Jan Michiel Otto, the different legal systems between common and civil laws have increasingly become smaller. Therefore, apart from differences in the legal system, the legal vacuum against copyright restrictions in Indonesia, as written in Article 44 of the Copyright Act, needs to address, and the comparative study has been inevitable.

There are several previous studies discussed the doctrine of fair use. Firstly, photocopying copyrighted works for educational purposes is written by Dharam Veer Singh and Pankaj Kumar at the National Law Institute University, Bhopal. ${ }^{1}$ The paper analyzes whether photocopying of

1 Dharam Veer Singh \& Pankaj Kumar, "Photocopying of Copyrighted Works for Educational Purposes: Does it Constitute Fair Use?” (2005) JIPR Vol 101 January 2005, online: <http://nopr.niscair.res.in/handle/123456789/3611. 
copyrighted works for an educational purpose constitutes fair use. ${ }^{2}$ The statutory provisions on the issue in different countries have been enlisted. ${ }^{3}$ The U.S. law has been exhaustively dealt with, followed by the guidelines as prescribed by the government body under the U.S. congressional mandate. ${ }^{4}$ A case analysis has been done to ascertain the courts' approach in applying the statutory provisions to the instances of making multiple copies of copyrighted works for educational purposes. Fair use under the U.S. statute depends on the four factors of purpose, nature, amount, and effect. The guidelines, however, make fair use dependent on brevity, spontaneity, and cumulative effect. ${ }^{5}$ In the last part of the paper, the prevailing U.S. law is compared with Indian law. ${ }^{6}$

Secondly, the paper analyses the Indonesian Copyright Act 2002, later amended to Law Number 28/2014 that remains a lack of strict regulation of copyright policy in Indonesia. The occurrence of emptiness law concerning the principle of fair use of some books' policymaking copies in library college. The purpose of this research is to analyze the form of regulation law on the principle of fair use in copyright associated with the policy of making copies of books in a library under the provisions of Indonesian Copyright and the Australian Copyright Acts.

Third, the implication of the fair use doctrine in Indonesia. This article discusses fair use (Article 43-49 Act 28/2014) of lecturers and researchers' scientific work. This legal discourse in the field of copyright law will be performed through doctrinal research. The critical finding states that the fair use doctrine allows scholars to utilize copyright-protected work from others under scientific or educational purposes - without obtaining prior consent or license. Nonetheless, the user of copyright-protected works must pay attention to the reasonable interest of the copyright holder, the meaning of which is left to legal practice. Fourth, the fair use doctrine in its history, application, and implications examines the fair use doctrine's understanding
Ibid.
Ibid.
Ibid.

5 Ibid.

6 Ibid. 
to become second nature. To this end, the author summarizes the salient points of law and fair use practice and demonstrates. In short, this paper examines whether the fair use doctrine can inform the teaching of writing in digital contexts. As teachers, researchers, and experts of writing, the discourse of fair use must be considered in addition to the discourse of plagiarism.

This study aims to analyze Indonesia's copyright issues, particularly regarding the reproduction of books deemed to have lesser protection for authors. Given the author's more protection, this study displays a comparative analysis of the U.S. framework on the Copyright Act portrayed into two main discussions. First, this study will discuss photocopying for educational purposes from the lens of Indonesia's Copyright Act. Second, this study considers the possible adjustment to adopt the so-called future concept of restrictions for educational purposes from the U.S. Copyright Act 1976.

\section{FAIR USE DOCTRINE IN THE RESTRICTION OF BOOK PHOTOCOPY FOR EDUCATION: AN ANALYSIS}

\section{A. Indonesia's Copyright Act 2014}

International agreements such as the Berne Convention, the TRIPs Agreement, and the WIPO Copyright Treaty do not explicitly explain the definition of creation and describes the types of creative works on creation only. This creative work is a type of work that is protected by copyright. Initially, copyright was concerned only with preventing the legal, physical use of printed material, but it has changed with technological development. This affects the development of types of creative works protected by copyright.

Article 2 the Berne Convention describes the types of works that are protected. However, the types of works mentioned are the minimum types of works that must be protected by copyright provisions in a country. However, the Berne Convention states that the extent to which each 
country's laws and regulations are applied to copyright provisions in the matter of the state itself. ${ }^{7}$ It asserts that each country has its authority in determining the implementation of these copyright arrangements. This is because both by adoption and using transplantation, a government can adopt an international scale regulation. One type of creation mentioned in Article 2 Berne Convention is a book.

The TRIPs Agreement explains that member countries must comply with the provisions contained in Article 1 to 21 of the Berne Convention, as stated in Article 9 (1) TRIPs Agreement. An exception also accompanies this article to the obligation to implement Article 6 and the rights derived from that article. In the TRIPs Agreement as a continuation of the Berne Convention, the arrangements regarding the types of works protected by copyright have no difference with those stipulated in the Berne Convention. However, only the types of covered works are further expanded, as contained in Article 10 TRIPs Agreement includes computer programs, compilation of data, both digital and other forms. There was a previous exception in Article 9 (2) TRIPs Agreement that the copyright protection is explicitly extended regarding expressions (fixation), not ideas, procedures, operating methods, or mathematical concepts.

Article 1 the Indonesian Copyright Act 2014 explains that creation is any copyrighted work in science, art and literature produced based on inspiration, ability, thought, imagination, talent, skill, or expertise expressed in tangible form. Copyright protection applies automatically when a work copyrightable is made. The Copyright Act requires fixation, a fundamental concept of copyright, which only protects the manifestation of work, so it does not have to do with the substance. ${ }^{8}$ The standards for protecting a new work based on this principle are relatively easy to meet regarding originality. Even new works involving only the most superficial variations of existing work can find protection. However, the creation must still be original, not plagiarism over other creations.

7 Desy Nurhayati, Tinjauan Hukum Hak Cipta Terhadap Aspek Penggunaan Komersial Terbadap Ciptaan Yang Menggunakan Lisensi Creative Commons (Depok: Skripsi Fakultas Hukum Universitas Indonesia, 2011) at 51.

8 Eddy Damian, Hukum Hak Cipta (Bandung: Alumni, 2009) at 98. 
Referring to this Copyright Act, a copyrighted work must have a distinctive form, be personal, and show originality as a creation that was born based on ability, creativity, or expertise so that the work can be seen, read, or heard. ${ }^{9}$ This means that copyright does not only protect ideas. Works protected by the Copyright Act are in three areas, namely art, literature and science. ${ }^{10}$ The three are detailed again in Article 40 of the Copyright Act, where one of the protected works is a book. It can be seen that a book is one of the creations that have a unique space in copyright protection, both in the Berne Convention, the TRIPs Agreement, the WIPO Copyright Treaty, and the Copyright Act. Thus, a book is an object of the copyright that has been recognized by all copyright regulations worldwide. This is because books are the intellectual property of a creator, which, apart from having an economic meaning for those who exploit them, also has an essential purpose for a nation's spiritual and material development. ${ }^{11}$

Books are literary expressions; what is essential to consider that the book as creation is that what is protected by copyright is the right, not the object. This means that what is protected by copyright is the right to reproduce books. ${ }^{12}$ Apart from adhering to the principle of fixation, books protected by copyright must also fulfill the declaration of originality (not an imitation of other people's work). Work as a whole is not an imitation of another author's written work. However, it must come from his work even though in creation in the form of a book, some parts may imitate or be inspired by other authors' writings. That is not including copyright infringement because it is not a copy in its entirety, but in part a sentence by inserting a comment according to the author's thought.

Books receive copyright protection as described in Article 40 of the Copyright Act, which avoids acts of copyright infringement by other parties

9 General Explanation Act No. 28/2014 on Copyright.

10 Budi Agus Riswandi dan M. Syamsudin, Hak Kekayaan Intelektual dan Budaya Hukum (Jakarta: Raja Grafindo Persada, 2004) at 10.

11 Imam Sya'roni Dziya' Urrokhman, Perlindungan Hukum Karya Cipta Buku Ditinjau Dari Undang-Undang Nomor 19 Tabun 2002 (Semarang: Tesis Magister Universitas Diponegoro) at 8.

12 Ok Saidin, Aspek Hukum Hak Kekayaan Intelektual (Jakarta: Raja Grafindo Persada, 1995) at 55. 
such as photocopying without permission from the author. Reproduction can be defined as multiplication, namely making something the same or similar, whether using the same material or not, by changing the reproduced creation or not changing the medium and type of creation. The right to reproduce a work in the form of a book or written work is part of the creator's rights. ${ }^{13}$ Photocopying work, such as a book or other written work, is a form of copyright infringement if done without the author's permission. It may be subject to punishment as set in Article 113. However, the Berne Convention then regulates copyright restrictions to recognize the need to promote science and creativity and balance creators and public interests, especially in education and research.

The Berne Convention, as the first convention resulted in an international agreement in the copyright, regulates the restrictions contained in Article 9 Berne Convention. The restrictions are set in Articles 10 and 13 of the Berne Convention that outline member countries through their national laws and regulations can determine the limits of these works' protection. In practice, these restrictions are related to de minimis doctrine or de minor reservations. ${ }^{14}$ It asserts that the minimal use of the work or the minimum requirements does not violate the author's exclusive rights based on this doctrine.

This provision contains the right of reproduction, which can be categorized as an article regulating book reproduction. The core of the coverage included in Article 9 of the Berne Convention is known as exploitation types. Copy of work, books, and other written assignments must not conflict with the author's normal exploitation. This article explains the complete protection of the creator or copyright holder to permit other parties who need the right to reproduce their works. An author is also given the right to prohibit other parties from reproducing a work, including written works or books. This propagation can be done in various forms or methods. For example, the reproduction of books using a photocopier or digitally.

13 Article 9 (1) Act No. 28/2014 on Copyright.

14 Rahmi Jened, Hukum Hak Cipta (Copyright Law) (Bandung: Citra Aditya Bakti, 2014) at 162 . 
Berne Convention is the subject of referral arrangements in Article 13 of the TRIPs Agreement. It deals with limitations and exceptions that set the three-step test to examine whether such restrictions are not abused. The main objective is to provide a balance between entitlements exclusive and limitation of exclusive rights. ${ }^{15}$ This three-step test justifies in line with the teleological argument because this test lies as a boundary between the author's exclusive rights and the privileges to use. ${ }^{16}$ The test includes three incremental steps, namely, basic rules: limitation must be certain exceptional cases, the first condition delimiting the basic rule: no conflict with a standard exploitation-compulsory license impossible, and the second condition delimiting the basic rule: no unreasonable prejudice to legitimate interestscompulsory possible permits. ${ }^{17}$ The first step states that restrictions are allowed for some instances, one of which is related to photocopying cases for educational purposes. The second step is that certain exceptional circumstances stated in the first step must not conflict with the fair use of a work. The third step is if using someone else's work without permission but not for commercial purposes does not reduce legitimate interest authors' prejudice.

As a legal consequence of the Berne Convention and the TRIPs Agreement's ratification, Indonesia is obliged to comply with the convention's rules. It is allowed to compile its national laws and regulations regarding copyright. This is because each convention member country has a different culture from one another. In addressing the protection of intellectual property rights, it is not the same.

The Copyright Act does not provide explicit regulations on the procedure for reproducing a work in the form of books or other written works. This does not mean that other parties who wish to reproduce books cannot take a reference. Article 1 of the Copyright Act states that copyright is an exclusive right for a creator that automatically arises based on the declarative principle after work is manifested in a tangible form without reducing restrictions on the provisions of laws and regulations. The exclusive right in question is a

\footnotetext{
15 Ibid at 157.

${ }_{16}$ Ibid.

17 Ibid.
} 
right reserved only for the creator. No other party can take advantage of the right without the author's permission; copyright that is not an author has a part of the exclusive right in the form of economic rights. ${ }^{18}$ However, due to the consequences of the ratification of international treaties, as previously explained, Indonesia also regulates copyright exceptions because the implementation of exclusive rights not only considers the protection of the creator but also takes into account the development of science and creativity. Thus, restrictions aim to balance the interests of creators or copyright holders with public interests.

Indonesia is a country that adheres to civil law. The civil law is not purely derived from Indonesian society. The legal system that is considered native to the Indonesian people is customary law and religious law. However, when Dutch colonized Dutch Indies, later so-called Indonesia, embedding civil law for three centuries in the administration, this system finally influenced and participated in this archipelagic government. After Indonesia started decolonization, it remains to apply most of the Dutch's general rules despite the recognition of adat laws and Islamic legal tradition. Over time, in its implementation, Indonesia is no longer fully implementing civil law.

Civil law is a tradition inherited from Roman law dating back to $450 \mathrm{BC}$. This tradition develops the concept of right, ethics, and state, which is essentially the existence of personality, influenced by GW Friedrich Hegel. ${ }^{19}$ Civil law's legal tradition is called natural rights justification, which views copyright as the creators' fundamental rights ${ }^{20}$ The author's right system as a system is a reward reflected in this legal tradition. The term limitation is a conception of civil law. ${ }^{21}$ This is because the starting point of copyright protection is given to the creator as the copyright subject with personal intellectual creation. The creator's exclusive right means that no other person may exercise the right, except with the creator's permission. The sect adhered to by the state civil law adheres to the philosophy that copyright is considered a natural right owned by the creator.

\footnotetext{
18 Explanation of Article 4 Act No. 28/2014 on Copyright.

19 Rahmi Jened, supra note 14.

20 Ibid.

${ }^{21}$ Ibid.
} 
The limitations in the Copyright Act are regulated in Article 43 to Article 51. Article 44 (1) of the Copyright Act aims that the exclusive rights owned by the creators prevent exploitation of copyright by others for commercial purposes. This limitation is also designed to regulate industrialization and commercial trade practices, and the existence of fair competition. ${ }^{22}$ So, there is no violation if other parties use a work for fair play.

Regarding adopting, rules contained in international treaties, not merely all rules are adopted into national legislation. It indicates that each country has its interests in its laws and regulations, particularly in protecting its intellectual property. It is impossible for Indonesia, as it ratified various international treaties on intellectual property rights, has contradictions in applying the adoption results into national legislation. It looks like it is about copyright restrictions for educational purposes. According to the Copyright Act, this act is not considered a copyright infringement, as provided that the source is included and does not harm the creator. ${ }^{23}$

Since the early development of copyright law, the importance of limiting it for educational purposes has been recognized. The limitation is currently closely related to intergenerational equity for generations' benefit to come as the two sides of coins are among today's users ${ }^{24}$ This means that users of work intend this limitation to appreciate a work more so that later writers feel that their work is appreciated and gives birth to new writers. When a country enjoys a creation, this will also impact the country's economy. In the form of a book, what has been created by the author later, the honorarium will be given to the author or author and given to the state as taxes.

The rules regarding copyright restrictions for educational purposes are contained in Article 44 (1) letter a, which is a qualitative article. Before the current Copyright Act was applied, the rules regarding copyright restrictions were still quantitative. The benchmark for how much other parties can use work is evident, namely as much as 10 percent of each work's unanimity on the condition that the source must be fully identified. ${ }^{25}$ The difficulty in

\footnotetext{
22 Ibid at 24.

${ }^{23}$ Article 44 (1) Act No. 28/2014 on Copyright.

24 Rahmi Jened, supra note 14 at 164.

${ }^{25}$ Article 15 Act No. 6/1982 on Copyright.
} 
determining a percentage of a work of art results in objections regarding the old provisions. The question of what if someone uses or reproduces someone else's written work because educational interests are less than 10 percent. Still, it is a substantial part. ${ }^{26}$ Thus, this reason is what makes the change from a quantitative article to a qualitative one.

The criterion for books can be photocopied for educational purposes in a textbook. The act of photocopying books for the sake of education when viewed from the perspective of the current Copyright Act by referring to Article 44 (1) letter a, then this action can be said to be a copyright violation and can also be said not to violate rights create. This is because the article only states, "... copyright infringement is not considered if the source is fully stated for educational purposes without prejudice to the reasonable interests of the creator." This means that this article is still qualitative because it does not explain how much other parties can say that it is not detrimental to the creator. Also, the definition and characteristics of educational interests themselves are not explained in detail in the Copyright Act to be fair use. Whether it is for educational purposes of a commercial or non-commercial nature, academic interests for private or public use, with a note, even though it is for educational purposes used for personal and non-commercial purposes, still must pay attention the reasonable interests of the creator.

When other parties as users make copies of a book or other written work, as often encountered in educational institutions (schools and universities), students reproduce texts as a whole, from cover to section, and keep the author's name used teaching material personal use. Unfortunately, regarding this action, there is still no affirmation that it goes beyond the meaning of the purpose of education itself. As a result, there are not only one or two who carry out this act of reproduction; many still do not understand the meaning of appreciating creation and consider the act of reproducing books for educational purposes. Every thought of the community, especially students and academics, will impact the creator's economic interests. Therefore, the reproduction of work for education must still consider the creator's financial interests. Do not let the economic benefits that should be felt by the creators

${ }^{26}$ Rahmi Jened, supra note 14 at 165. 
completely disappear with the existence of regulations regarding copyright restrictions.

\section{B. The United States' Copyright Act 1976}

Provisions regarding copyright exceptions are to encourage the development of science and creativity and balance creators' interests and the public's interests. This provision is then adopted into copyright law in Indonesia. However, there is a contradiction about these provisions stated in the Copyright Act regarding copyright limitation for educational purposes. The article does not explain how many other parties can use or reproduce a work that is not considered detrimental to the creator. Therefore, Indonesia also needs to refer to book reproduction guidelines adopted by common law countries such as the U.S., which already have regulations on copyright. Law enforcement in the U.S. is more advanced than in Indonesia.

The United States follows the common law tradition influenced by John Locke, an English philosopher. His claim deals with the concept of property related to human rights with the statement of life, freedom, and ownership. ${ }^{27}$ Locke believed that man should be rewarded for his labor, regardless of form. ${ }^{28}$ The tradition is a common law system called "functionalist justification," as an incentive system that defines copyright protection as an economic instrument to increase knowledge and support socio-economic development. ${ }^{29}$ As a copyright system, the object of copyright or creation (copyrighted work) is the starting point of protection. Access to fair use of a work is granted to the public. ${ }^{30}$ This has led to the Common Law giving the term fair use or fair dealing. About protected works, apply restricted rights that the community is not allowed, except for fair use.

If copyright is a legal metaphysics, fair use is semiotic. The term fair use is known in the U.S. Copyright Act 1976 as a norm that limits authors' exclusive rights. Compared to all existing provisions in copyright, the doctrine of fair use is often difficult to understand. This doctrine stipulates

\footnotetext{
${ }^{27}$ Ibid.

28 Ibid.

${ }^{29}$ Ibid.

${ }^{30} \mathrm{Ibid}$.
} 
that work is allowed on a limited basis for use by another party without the creator or copyright holder's permission to retain the nature of a fair. ${ }^{31}$ Even so, the U.S. Copyright Act 1976, which applies in the United States, does not clearly define fair use. This regulation only states that the doctrine of fair use is a defense against claims for copyright infringement. ${ }^{32}$

The U.S. Copyright Act 1976 states that criticism, commentary on news reports, teaching (including reproduction of copies for classroom use), science, or research are types of purposes that can justify examining fair use. ${ }^{33}$ The rules that have been mentioned above also provide general guidelines for determining fair use whether or not. These guidelines are set out in Section 107 of the Copyright Act 1976 (Limitations on Exclusive Rights: Fair Use). The fair use doctrine involves balancing between a set of variables that determines whether other interests can overrule the creator's rights. Section 107 of the 1976 Copyright Act explicitly identifies four factors to determine fair use, including the purpose and character of the use, the nature of the work, the proportion or share took, and economic consequences.

Other literature also adds two guidelines apart from the four factors above, namely the intent and reasons of other parties in using the work. The connection with this is if the other party does not have a reason for profit; for example, his action is carried out solely for the benefit of education, personal interest. It cannot qualify as a commercial profit-seeking interest. ${ }^{34}$ The doctrine considers several different interests so that it is a complex issue in copyright law institutions. ${ }^{35}$ Therefore, the other party cannot necessarily argue that their act of reproducing a work has been excluded by fair use. As the party with authority to determine fair use interest or not, the court has a vital role in answering this matter.

In this section, four factors are described in Section 107 of the Copyright

${ }^{31}$ Eddy Damian, supra note 8 at $120-121$.

32 Arthur R. Miller and Michael H. Davis, Intellectual Property: Patents, Trademark, and Copyright, in A Nutshell, (Minnesota: West Publishing, 1990) at 348.

33 Section 107 U.S. Copyright Act 1976.

${ }^{34}$ C. Anwar, Hak Cipta, Pelanggaran Hak Cipta, dan Perundang-undangan Baru Hak Cipta di Indonesia (Jakarta: Novindo Pustaka Mandiri, 1999) at 29.

${ }^{35}$ Ibid. 
Act 1976 to determine whether the use of a work is fair use or not. The first is the purpose and character, including its commercial nature. This purpose and character is a dualistic concept of commercial use versus non-commercial use and public use versus private use. The dynamism of fair use involves interrelated factors rather than determining factors. However, no doctrine mandates solely that non-commercial purposes and personal use are automatically fair use. However, the non-commercial nature of the use and its character are very persuasive in determining fair use or not in this use. ${ }^{36}$

The U.S. Copyright Act 1976 does not separate the terms non-profit and education; it is not clear that fair use for educational purposes should always be non-profit or not. ${ }^{37}$ Simultaneously, it is not surprising that when elements of educational objectives and non-profit institutions meet in the same defense, the result is not necessarily fair use. This could be due to the creation's nature, namely the text whose market is expected in an educational environment. The substantiality of its reproduction far exceeds the other party's non-profit educational goals. ${ }^{38}$ In conclusion, perhaps one accurate way of highlighting this purpose and character is by testing a profit motive that almost certainly rejects fair use. Whereas what is said to be in the interests of education, criticism, or others, the court views it as chiseling for personal profit. ${ }^{39}$ Courts are even more supportive of uses that are transformative than those that are reproductive (resembling the original or only in photocopy). This means that when a copyrighted work is changed into something new or a new utility, it is possible to say it is fair use.

Second, namely the nature of creation, the creation's nature can be measured through the creativity and originality invested by the creator. A work that describes two characteristics (creativity and originality) that deserve consideration has a smaller chance of fair use than with a mass-produced with minimal creativity and originality levels. This statement's purpose is that creation with high creativity and originality is used by someone who is not entitled to make it difficult for that party to fight the lawsuit on the

${ }^{36}$ Arthur R. Miller and Michael H. Davis, supra note 32 at 352.

37 Ibid.

${ }^{38}$ Ibid at 353-354.

39 Ibid at 353. 
grounds of fair use. Nevertheless, it is different if creation has minimal creativity and originality and is also created by many people. This is undoubtedly easier for someone who uses the work to defend other parties' claims on the grounds of fair use.

The nature of creation can be measured through the creativity and originality invested by the creator. ${ }^{40}$ Suppose the nature of work is inevitable, and another party's use lies in the same area as the work's potential benefits. In that case, this does not support fair use. ${ }^{41}$ For example, work is the creation of education. The market intended for using the work by other parties is also in education. Thus, this is not legitimate to be called fair use. Fair use can also be used for both published and unpublished works. ${ }^{42}$ It is challenging to prove fair use in the use of works that have not been published, such as documents or personal letters unless unethical or illegal practices appear in work. This is due to the inherent right to first publication on works that have not been published. The nature of works that have not been issued is very likely to incriminate fair use defense. ${ }^{43}$

Third, testing the proportion or partly taken. David Naver explained that the most important thing that needs to be asked and answered from this test is whether other parties take part or reproduce a creation more than is necessary for its purpose. ${ }^{44}$ The general principle commonly heard from this third factor is the more taking, the more infringement. The meaning of the word more indicates that the word is qualitative and quantitative. This means that part three of Section 107 Copyright Act 1976 stipulates that an assessment qualitatively and quantitatively is necessary.

Quantitative assessment is carried out by paying attention to the number or proportion taken. In contrast, a qualitative assessment is carried out by paying attention to the part substantially taken. For example, a student takes the entire contents of a book chapter to be reproduced, quantitatively it is

40 Ibid at 356.

41 Ibid at 355.

42 Ibid at 351.

${ }^{43}$ Desy Nurhayati, supra note 1 at 71.

44 David Naver, Intellectual Property Law: Copyright, Patent, Trademark (Ontario: Irwin Law, 1997) at 105. 
considered a lot, but its nature is not too substantial, it may not be a copyright violation. It is different from taking a small part in a book's contents, even though it is tiny quantitatively. Still, it is very substantial, or the basis is the essence of the work. Qualitatively, the taker's action may be considered unfair or violating copyright.

In essence, the framework that can be inferred is how much and how substantial the portion is taken. Therefore, before determining whether the use of another party is fair, it must first be determined whether its use is in violation or not.

Qualitative reproduction of creations should not exceed the educational goals to be achieved. A quantitative examination is also carried out by taking into account the number of parts taken from the original work, not the whole. To determine the benchmarks for the proportion of features that can be used, the academic community and book publishers have agreed to apply classroom guidelines for book reproduction even though they are not listed in the law. ${ }^{45}$ In the end, it was agreed that other parties could only reproduce books at a maximum of $10 \%$ or a thousand words from the entire book page. Especially for book creation, reproduction for the benefit of classroom lessons and research can only be done once for the teacher. Many copies are allowed for one student per class if one chapter of the book is short enough, copied spontaneously, and according to the test. Cumulative effect. ${ }^{46}$ Not only that, several other written works such as poetry, picture books (comics, children's books), sheet music also have their respective provisions, what percentage can be reproduced.

The fourth is the economic effect of taking. Testing the economic consequences of this take assesses how other parties' use of the work (users) affects a work's potential market. This economic effect can also be determined by how much or how important the work is. The use of multiple shares can affect the market effect of the creator's property and or the use of

45 United States Copyright Office, "Reproduction of Copyrighted Works by Educators and Librarians, "online: <http://www.copyright.gov/circs/circ21.pdf>.

46 Dharam Veer Singh and Pankaj Kumar, Photocopying of Copyrighted Works for Educational Purpose: Does it Constitute Fair Use? (2005) 10:1 Journal of Intellectual Property Rights, at 23. 
small parts. Still, a substantial amount or core of the work can also affect the creator's property's potential market effects because the harvest is very economical. ${ }^{47}$ In some circumstances, a small part of the quote may not damage the work's potential in question. This is because a section may not be a substitute for using a work; for example, a writer quotes a sentence from another author's book, puts it in his published book, and then trades it on campus for educational purposes. ${ }^{48}$ The author who quotes it may not have violated fair use because it does not necessarily make the other party (readers) think not to buy the book from the author whose sentence has been quoted. This factor is a critical factor in fair use because it connects and makes other elements defense of fair use simultaneously. However, this last factor is not merely a determinant of a work being said to be fair or not. Other factors are also essential to consider and determine. It is only used to estimate whether there is a loss to the creator for using other parties' work. However, choosing how much to lose from this creator's potential market is very difficult to quantify. Rarely found exact numbers. Thus, in giving judgments, the court must be observant because of this factor's difficulty to prove.

Determining whether a use is fair use or not can only be concluded with only one factor; for example, using work for educational purposes has been declared as fair use. However, it is still necessary to evaluate, apply, and weigh in the balance the nature of the work, the substance of the parts used, and the economic consequences of market use or the value of the work. In essence, it needs to be underlined that even though there is a provision for reproduction for educational purposes in the U.S. Copyright Act 1976, it still has to meet the four factors in Section 107 of the U.S. Copyright Act 1976. After answering the four elements, the impression is born whether the act of reproduction is considered, whether fair or not.

According to John Henry Merryman, to copy the U.S. copyright model, convergence is considered more appropriate. The Civil Law and Common Law are increasingly similar rather than significantly different. Therefore,

47 Arthur R. Miller and Michael H. Davis, supra note 26 at 360-361.

48 USG Copyright Policy, "The Fair Use Exception," Online: <http://www.usg.edu/ copyright/the_fair_use_exception>. 
apart from differences in legal systems, there should be legal obscurity to copyright exceptions in Indonesia for educational purposes as stipulated in Article 44 (1) of the Copyright Act can find solutions by using the comparative law method or using legal transplants to obtain objective results. ${ }^{49}$

Cases regarding copyright restrictions in photocopying work such as books or other written works have never existed in Indonesian judicial practice. ${ }^{\mathbf{5 0}}$ Whereas we often encounter, especially in school environments and campus, users' actions to multiply books even as a whole are used for educational purposes. This is because many people take copyright protection lightly and think that making copies of books for the sake of academic reasons is a lawful act. Therefore, it is necessary to reinforce copyright protection. It is expected that the entire community will be able to realize it to better respect copyright. A more specific way to provide copyright protection to works is by revising the provisions regarding copyright exceptions as contained in Article 44 (1) letter a of the Copyright Act. They are not only qualitative but also quantitative. Of course, this is regarding the article's determination, namely how many proportions can be used or made reproduction of a work. For that, we need a mutual agreement by both authors, academics, and a photocopy shop in determining the number of parts to be used or reproduced on a creation that will serve as guidelines. It is also necessary to have an exact meaning regarding what kind of educational interest is meant in Article 44 (1) letter a, whether it is non-commercial academic interests or not, for private use or public use.

Other parties (users) who will use a work or work belonging to the creator must be carefully examined. For example, another party, namely a student making a copy of work because it may only use as much as $10 \%$ of the book's total contents for educational purposes. Also, the reasons for the importance of education do not merely make it an act of fair use. Even though education

49 Choky R. Ramadhan, Convergence of Civil Law and Common Law in Indonesia in the Discovery and Formation of Law, (2018) 30:2 Mimbar Hukum, at 215.

50 Kristian Takasdo and Agus Sardjono, Fair Use in the Copyright Protection System: A Comparative Study Between Indonesian Copyright Law and United States Copyright Law, (Depok: Thesis Faculty of Law University of Indonesia, 2013) at 2. 
interests are one of the exceptions to copyright, it must still be considered whether the parts of education in terms of whether education is profitable. There need to be strict sanctions, both administrative and criminal sanctions related to this issue, so that creators in Indonesia feel that their creations are respected. If things are implemented, new creators can create designs without any fear of actions like this, which will have a good impact on the Indonesian economy.

\section{CONCLUSION}

Indonesia's copyright law concept needs a considerable adaptation through the legislative revision to include copyright exceptions for more specific educational purposes. By referring to the U.S. Copyright Act, the regulation regarding book reproduction in the U.S. is quite detailed and strict. This precise and strict regulation shows a higher awareness of the importance of copyright in the U.S. society responded by the government to provide a legal basis for protection. Thus, Indonesia's current challenges and opportunities can refer to the existing U.S. Copyright Act even though both countries have different legal systems and traditions.

\section{REFERENCES}

Anwar, Chairul. Hak Cipta, Pelanggaran Hak Cipta, dan Perundangundangan Baru Hak Cipta di Indonesia (Jakarta: Novindo Pustaka Mandiri, 1999).

Damian, Eddy. Hukum Hak Cipta (Bandung: Alumni, 2014).

Dharam Veer Singh \& Pankaj Kumar, "Photocopying of Copyrighted Works for Educational Purposes: Does it Constitute Fair Use?" (2005) JIPR Vol 101 January 2005.

Jened, Rahmi. Hukum Hak Cipta (Copyright's Law) (Bandung: Citra Aditya Bakti, 2014).

Miller, Arthur R. and Michael H. Davis. Intellectual Property: Patents, Trademarks, and Copyright, in A Nutshell (Minnesota: West Publishing, 1990) 
Naver, David. Intellectual Property Law: Copyright, Patents, Trademarks (Ontario: Irwin Law, 1997).

Nurhayati, Desy. Tinjauan Hukum Hak Cipta Terhadap Aspek Penggunaan Komersial Terhadap Ciptaan Yang Menggunakan Lisensi Creative Commons, Skripsi (Depok: Fakultas Hukum Universitas Indonesia, 2011).

Ramadhan, Choky R. "Konvergensi Civil Law dan Common Law Di Indkum,ia Dalam Penemuan dan Pembentukan Hukum" (2018) 30:2 Mimbar Hukum.

Rife, Martine Courant. The Fair Use Doctrine: History, Application, and Implications for (New Media) Writing Teachers, The Fair Use Doctrine: History, Application, and Implications for (New Media) Writing Teachers, Writing Program, Department of Communication, Lansing Community College, Lansing, MI, USA, 2007.

Riswandi, Budi and M. Syamsudin. Hak Kekayaan Intelektual dan Budaya Hukum (Jakarta: Raja Grafindo Persada, 2004).

Saidin, OK. Aspek Hukum Hak Kekayaan Intelektual (Jakarta: Raja Grafindo Persada, 1995).

Singh, Dharam Veer and Pankaj Kumar. Photocopying of Copyrighted Works for Educational Purpose: Does it Constitute Fair Use? (2005) 10:1 Journal of Intellectual Property Rights.

Sudjana, Implikasi Doktrin "Fair Use" Terhadap Pengembangan Ilmu Pengetahuan oleh Dosen atau Peneliti Dalam Perspektif Hukum Hak Cipta (Bandung: Fakultas Hukum Universitas Padjadjaran, 2018).

Takasdo, Kristian and Agus Sarrdjono. Fair Use Dalam Sistem Perlindungan Hak Cipta: Suatu Studi Perbandingan Antara Undang Undang Hak Cipta Indonesia Dengan Copyright Law Amerika Serikat, Skripsi, (Depok: Faukltas Hukum Universitas Indonesia, 2013).

U.S. Copyright Office, "Reproduction of Copyrighted Works by Educators and Librarians" online: <http://www.copyright.gov/circs/circ21.pdf>.

Urrokhman, Imam Sya'roni Dziya'. Perlindungan Hukum Karya Cipta Buku Ditinjau Dari Undang-Undang Nomor 19 Tahun 2002, Tesis (Semarang: Fakultas Hukum Universitas Diponegoro). 
USG Copyright Policy, "The Fair Use Exception," online: <http://www.usg.edu/copyright/the_fair_use_exception>.

Widowati, Retno Sari. Penerapan Prinsip Fair Use Dalam Hak Cipta Terkait Dengan Kebijakan Perbanyakan Buku di Perpustakaan Perguruan Tinggi (Studi Perbandingan Hukum Berdasarkan UndangUndang Hak Cipta di Indonesia Nomor 28 Tahun 2014 dan Australia) (Malang: Fakultas Hukum Universitas Brawijaya, 2015). 
124 | Fair Use Doctrine in Photocopying Books for Educational Purposes

This page intentionally left blank 